\title{
Knowledge, attitude and practice of mothers towards female genital mutilation in South West Shoa zone, Oromia region, Ethiopia
}

\begin{abstract}
Background: Female genital mutilation is a long held tradition in the society of Ethiopia. It has significant drawbacks leading women of all age to different forms of morbidity and mortality. Assessment of KAP of mothers of child bearing age is an important measure towards the movement of discharging this long held tradition from the society.
\end{abstract}

Objective: To assess the knowledge, attitude and practice of mothers of child bearing age towards FGM in Obi koji Kebele, Wolisso woreda South, West Shoa zone, September 2009.

Method: A descriptive cross-sectional study was conducted from July 18 to August 09/ 2009 in Oromia region, South West Shoa zone, Wolisso woreda, Obikoji Kebele. A total of 384 sampled mothers were interviewed using a face to face interview. A systematic sampling technique was used to select the sampled households. The data processing was made by entering coded variables accordingly in to a computer SPSS version 16 and obtained the corresponding frequency counts for each variable. Finally, analysis was made by interpretation of frequencies, tables and graphs. Chi-square test was used to determine statistical association between variables.

Results: Three hundred twenty four $(84.4 \%)$ of the mothers responded that FGM can lead to a health problem, while $58(15.1 \%)$ of the mothers said that FGM does not lead to any health problem. Among the mothers who know the possible problems that could occur as a complication of FGM $128(39.5 \%)$ responded that the problem occurs immediately after the procedure (bleeding) and during child birth. Among respondents $370(96.4 \%)$ claimed that the practice is abandoned by law and is punishable, while $12(3.1 \%)$ of the mothers responded it has no legal provision. Three hundred thirty five $(87.2 \%)$ of respondents do not want their daughters to be circumcised and need to avoid FGM in the future, and 49(12.8\%) want to continue with FGM. Maternal education has very significant association with mothers' knowledge, attitude and practice about FGM with p-value of $0.000,0.005$ and 0.000 , respectively. Mothers who had access to different kinds of mass media were more likely found having good knowledge, attitude and practice than mothers who had no access to any kind of mass media ( $p=0.001$ for each). Maternal age was another variable which has very significant association with knowledge, attitude and practice of mothers with p-value of $0.001,0.021$ and 0.000 respectively. This study showed the magnitude of FGM to be $63.7 \%$.

Conclusion: This study showed that maternal education, access to different kinds of mass media and maternal age have significant effect on mothers' knowledge, attitude and practice about FGM.

Keywords: knowledge, attitude, genital mutilation, FGM, victim, labia minora, clitoris, infibulation, vaginal orifice, cauterization, ill begotten attitude, misconception, religious, koran, holy bible, obikoji kebele, taboo, feto
Volume 6 Issue 2 - 2017

\section{Semere Sileshi Belda,Abdurahman Kalu Tololu}

Madda Walabu University, Goba Referral Hospital, Ethiopia

Correspondence: Abdurahman Kalu Tololu, Madda Walabu University, Goba Referral Hospital, Ethiopia, Tel +251924545690, Email abdurehmankelu900@gmail.com

Received: May 14, 2017| Published: June 19, 2017
Abbreviations: AHOTP, accelerated health officers training program; CI, confidence interval; DF, degree of freedom; EWLA, Ethiopian women lawyers association; FGC, female genital cutting; FGM, female genital mutilation; HTP, harmful traditional practice; IEC, information education and communication; KAP, knowledge attitude and practice MDG, millennium development goal; NCTPE, national committee of traditional practices of Ethiopia; P, p-value; UNICEF, united nations international children fund; WAO, women's affairs office; WHO, world health organization

\section{Introduction}

\section{Background}

Female genital mutilation (FGM), by definition is the removal of female genitalia partially or completely for non-medical reason. Female genital mutilation (FGM) and female circumcision are two terms that refer to the practice of removing parts of the women's genitalia. The former is used by World health organization (WHO), while the latter is used by the community where this custom is 
practiced. The practice of FGM and the type of operation are often specific to particular ethnic groups and thus the prevalence varies widely within and between countries. Type III FGM is found mainly in Somalia and Somali groups in surrounding countries, Djibouti, Eritrea, and Sudan (excluding southern Sudan) and in Borena ethnic groups in Ethiopia.

According to WHO there are four types of FGM, these are:

i. Type I FGM, which is excision of the prepuce with partial or total removal of the clitoris,

ii. Type II FGM, which is excision of the clitoris with partial or total removal of the labia minora,

iii. Type III FGM (infibulation), which is excision of the labia majora with stitching or sealing of the vaginal orifice, and

iv. Type IV FGM, is unclassified which includes, the range of practices as stretching of labia and clitoris, burning of the clitoris and adjacent tissues by cauterization. ${ }^{1}$ FGM exists primarily in Africa and in certain communities in the Middle East and Asia. It is practiced in 28 countries in Africa and at a rate of at least $50 \%$ in more than $60 \%$ of the countries. It is not well known when and where the tradition of FGM is originated, but some people believe the practice started in ancient Egypt. The highest incidence of FGM has been reported in Somalia (98\%), Djibouti (98\%), Eritrea (90\%), Serra lion (90\%), Sudan (85\%), Egypt (80\%), and Gambia (80\%). It is estimated that between 100 and 400 million girls and women have experienced FGM, respectively, and that at least 2million girls undergo some forms of such mutilation every year. ${ }^{2}$

Many harmful traditional practices (HTP) such as FGC are deeply entrenched in the society of Ethiopia in general and the study area in particular, for which reason they are regarded as just and beneficial acts by many. Also in as much as the practices are harmful to the victim there are also pockets which benefit from it. Needless to say women are victims of harmful traditional practices in general and FGM in particular in the community. These practices violet their marital, reproductive health, physical and spiritual rights and wellbeing in a number of ways, as they are subject to different forms of FGM right from the date of their birth, all the way to the time of giving birth. ${ }^{3}$ Despite different constitutional provisions the hard reality on the ground reveals a shedding picture, some of the factors contributing for this discrepancy may be cultural and religious belief related factors such as gender inequality, an ill begotten attitude towards women's reproductive organs, and the need to secure wife's fidelity to husband. Moreover, socio economic factors as poor access to information, not educating women or legal related factors as poor enforcement of the law, and reluctantness of the law enforcement organs to regard FGC as an act that reveal bodily harm are other factors incriminated. ${ }^{1,3}$ There is a misconception that FGM is a religious obligation. However, FGM cannot be related to either Islamic or Christianity because of the following reasons: FGM is not practiced in all Islamic countries, It is not practiced in all Christian countries, there is strong historical evidence that it pre-dated the arrival of Islam in Africa, the Koran does not prescribe the performance of FGM, there is no reference to female circumcision in the old or new Testament of the Holy Bible. Because of the resulting physical and physiological hazards it brings to the life of the circumcised girl, Christianity rejects FGM. ${ }^{4}$ The statement by Islamic jurists also demonstrate that society is capable of emphasizing those religious believes which serve its economic interest. Female circumcision persists because of economic and political factors. Saadawi contends that in an attempt to hide the true reasons for events, religious arguments are used to obscure the economic and political factors which actually shape history. ${ }^{5}$ Obikoji is one of the rural kebeles in Wolisso woreda, where majority of the community are dependent on farming for their life. As the other rural communities in the country it is the male who is the decision maker of the family and women are dependent on the male in their life, even they need their husbands to decide on their health related issues. Mothers are not educated and have little access to information about reproductive health and other health related issues. Thus assessing the Knowledge, attitude and practice (KAP) of mothers towards FGC is the get point to fight against the practice. ${ }^{6}$

\section{Significance of the study}

Assessing the KAP of the main victims of FGM is a very important measure towards the movement of discharging this long held tradition from the society which is suffering from its immediate as well longterm consequences. It has a great significance in the preparation for bringing an attitude change in mothers and to empower them above all by understanding that most common reasons for the practice of FGM stem from direct or indirect attitude of down grading women and looking at them as beings created to serve the other sex and it is this social attitude which is playing an important role that needs to be destroyed in order to achieve at behavioral change. Improvement of maternal health is incorporated in the millennium development goals (MDG) as one of the prerequisites for development and poverty reduction. ${ }^{7}$ Therefore, it is essential to describe their KAP before all actions that will be forwarded for improvement of maternal health. The study results will be used at all levels that are hoped to play a part in the improvement of maternal health ranging from the healthcare planners to those working in the periphery and by others who want to use the study result for their study in related topics in the future.

\section{Objective \\ General objective}

To assess the knowledge, attitude and practice of mothers of child bearing age towards FGM in Obikoji kebele, Wolisso woreda South, West Shoa zone, April 2009.

\section{Specific objectives}

i. To measure the magnitude of FGM in daughters of mothers living in Obikoji kebele.

ii. To assess the knowledge of mothers about harmful effects of FGM.

iii. To assess the attitude of mothers towards FGM.

iv. To assess the practice of mothers in subjecting their daughters to FGM.

\section{Methodology}

\section{Study area and period}

The study was conducted from July 18 to August 09/ 2009 in Oromia region, South West Shoa zone, Wolisso woreda, Obikoji kebele, which is found at $3.5 \mathrm{Km}$ to the east of woliso town and at $110.5 \mathrm{Km}$ from the capital city Addis Ababa to the west. The kebele is bounded by Dilala kebele in the east, Wolisso town in the west, Ijarsa Kojii kebele in the south and Dembali keta kebele in the north. It has 508 Gares and 169 Gotts, with a total house hold of 5089 and 
total population of 25668 people, of which 12711 (50.3\%) are male and $12557(49.7 \%)$ are female. Located at an attitude of 2180 meters above sea level, an average rain fall of $1202 \mathrm{~mm}$, its weather condition is woynadega, with plain and hilly arrangement covered with green vegetables, average room temperature of 22.5 degree Celsius. The community in Obikoji kebele has good access to transportation as the kebele is located on the main road running from Addis to Wolisso, has good access to health facilities compared to other kebeles in the woreda, there is one health post and one clinic in the kebele and it takes less than an hour to reach the nearby health center and hospital. There is one elementary school in the kebele..$^{8-12}$

\section{Study design}

A descriptive cross-sectional study design was used.

Population

\section{Source population}

The source population for this study was all women of child bearing age living in Obikoji kebele.

\section{Study population}

The study population was a group of sampled mothers from women of child bearing age living in Obikoji kebele.

\section{Sample size}

A total of 384 sampled mothers were interviewed, using a single proportion formula, assuming that, the proportion of the prevalence of knowledge of mother about FGM is $50 \%$, adding a non-response rate of $5 \%$.

\section{Sampling technique}

A systematic sampling technique was used to select 384 mother of the sampled households with interval constant $\mathrm{k}=13$.

\section{Variables, instruments and measurements \\ Dependent variables}

Prevalence of FGM, Knowledge, attitude and practice of mothers were the major dependent variables.

\section{Independent variables}

The factors such as educational status, availability of mass media in the households, religion, ethnicity and family income were the explanatory variables.

\section{Instruments}

A well-structured questioner was used to collect pertinent data The questionnaire was pre tested one week before the actual data collection in randomly selected 20 households in the kebeles and preliminary modifications were made in it.

A computer software, Pencils, Erasers and sharpener constitute some of the instruments were used for the study.

\section{Data collection methods}

We had contacted the kebele administrators with a formal letter from the office of the coordinator of AHOTP St. Luke Hospital after we get an approval for the project to proceed, and then pertinent data was collected using a pre tested questioner by face to face interview from the appropriate respondent.

\section{Data processing and analysis}

The data processing started during the data collection by checking the completeness and accuracy of the data, sorting of the data by numbering the questionnaires. Quality control checks were made in order to recheck the completeness and internal consistency to be sure that there is no missing data for each variable before the final analysis was made. We categorized and coded variables accordingly to the possibility of responses obtained from respondents. We entered the coded data in to a computer SPSS version 20 program and obtained the corresponding frequency counts for each variable. Finally, the analysis was done by interpretation of frequencies, tables and graphs, chi-square and $\mathrm{p}$-value wherever appropriate.

\section{Operational definition of variables}

\section{Knowledge}

i. Good Knowledge, those answered $>8$ correct answers from 11 knowledge assessment questions.

ii. Fair knowledge, those answered 4 to 7 correct answers from 11 knowledge assessment questions.

iii. Poor knowledge, those answered $<4$ correct answers from 11 knowledge assessment questions.

\section{Attitude}

Mothers are categorized on their correct response to those questions asked to assess their attitude towards FGM.

i. Favorable attitude, those mothers who do not want female circumcision to be continued in their daughters and in the community in the future.

ii. Unfavorable attitude, those mothers who want their daughters to be circumcised in the future.

\section{Practice}

i. Mothers who had circumcised her daughters.

ii. Mothers do not circumcised any of her daughters.

\section{Ethical consideration}

Permission to carry out the study was obtained from the kebele administration using a cooperation letter written to the kebele administrators by the program coordinator of St. Luke Hospital before all and a verbal consent was obtained from the participant mothers from whom information was obtained after explaining the objective of the study. All responses were kept confidential.

\section{Limitations of the study}

There may be an information or recall bias as mothers were asked to recall events occurred long time.

\section{Result}

\section{The socio demographic characteristics of respondents}

There were 384 mothers of the reproductive age group interviewed yielding a response rate of $95 \%$; the mean age of the mothers was 33 years. Of the mothers interviewed $292(76 \%)$ were married women, 
$63(16.4 \%)$ were widowed, $22(5.7 \%)$ were divorced and the remaining $7(1.8 \%)$ are single according to their marital history. The educational status of the mothers showed: illiterate $165(43.0 \%), 99(25.8 \%)$ grade 1-6, $108(28.1 \%)$ grade $7-12$, and $12(3.1 \%)$ were have attended above grade 12. Their source of income demonstrated $335(87.2 \%)$ farming (house wife's), 14 (3.6\%) governmental employs, 19 (4.9\%) merchants, 16 (4.2\%) earn from other sources (Table 1).

Table I Socio-demographic characteristics of respondents, Obikoji kebele, Wolisso woreda, South west shoa zone, Aug- Sep. 2009, $(n=384)$

\begin{tabular}{|c|c|c|}
\hline Variable & Frequency & Percent \\
\hline \multicolumn{3}{|c|}{ Age in years } \\
\hline $15-19$ & 22 & 5.7 \\
\hline $20-24$ & 56 & 14.6 \\
\hline $25-29$ & 83 & 21.6 \\
\hline $\begin{array}{l}30-34 \\
35-39 \\
40-44 \\
45-49\end{array}$ & $\begin{array}{l}60 \\
67 \\
57 \\
39\end{array}$ & $\begin{array}{l}15.6 \\
17.4 \\
14.9 \\
10.2\end{array}$ \\
\hline \multicolumn{3}{|c|}{ Marital status } \\
\hline Married & 292 & 76.1 \\
\hline Widowed & 63 & 16.4 \\
\hline Divorced & 22 & 5.7 \\
\hline Single & 7 & 1.8 \\
\hline \multicolumn{3}{|c|}{ Educational status } \\
\hline Illiterate & 165 & 43 \\
\hline Grade I-6 & 99 & 25.8 \\
\hline Grade 7-12 & 108 & 28.1 \\
\hline Grade $>12$ & 12 & 3.1 \\
\hline \multicolumn{3}{|l|}{ Ethnicity } \\
\hline Oromo & 342 & 89.0 \\
\hline Gurage & 16 & 4.2 \\
\hline Amhara & 25 & 6.5 \\
\hline Others & I & 0.3 \\
\hline \multicolumn{3}{|c|}{ Annual income(ETB) } \\
\hline$<1500$ & 82 & 21.4 \\
\hline $1500-4999$ & 138 & 35.9 \\
\hline $5000-10000$ & 109 & 28.4 \\
\hline$>10000$ & 55 & 14.3 \\
\hline \multicolumn{3}{|l|}{ Religion } \\
\hline Orthodox & 210 & 54.7 \\
\hline Protestant & 161 & 41.9 \\
\hline Muslim & 8 & 2.1 \\
\hline Catholic & 4 & 1 \\
\hline Other & 1 & 0.3 \\
\hline
\end{tabular}

\section{Knowledge of respondents about FGM}

All $(n=384)$ of the mothers interviewed have heard about FGM, among them $378(98.4 \%)$ responded that the procedure is performed by cutting the clitoris and the remaining $6(1.6 \%)$ as it is performed by piercing the prepuce. Three hundred twenty four $(84.4 \%)$ of the mothers responded that FGM can lead to a health problem, while fifty eight $(15.1 \%)$ of mothers said that FGM does not lead to any health problem. Among the mothers who know the possible problems that occur as a complication of FGM the majority (39.5\%) indicated that problems occur immediately during the procedure (bleeding) and during child birth (Table 2). Among the mothers interviewed $370(96.4 \%)$ responded that the practice is abandoned by law and is punishable either to the parents or the circumcisers or both, while $12(3.1 \%)$ of the mothers responded it has no legal provision.

Table 2 Knowledge of mothers about the time of occurrence and types of complications of FGM, Obi koji kebele,Wolisso woreda, South west shoa zone, Aug- Sep. 2009

\begin{tabular}{|c|c|}
\hline $\begin{array}{l}\text { Possible time of occurrence } \\
\text { of a complication }\end{array}$ & Frequency(Percentage) \\
\hline \multicolumn{2}{|c|}{$\begin{array}{l}\text { During the procedure \& time of } 128(39.5) \\
\text { delivery }\end{array}$} \\
\hline Only during time of delivery & $108(33.3)$ \\
\hline Only during the procedure & $32(9.9)$ \\
\hline $\begin{array}{l}\text { During sexual intercourse, the } \\
\text { procedure \& Time of delivery }\end{array}$ & $39(12.0)$ \\
\hline $\begin{array}{l}\text { During sexual intercourse \& } \\
\text { time of delivery only }\end{array}$ & $8(2.5)$ \\
\hline \multicolumn{2}{|c|}{$\begin{array}{l}\text { During sexual intercourse \& the } 7(2.2) \\
\text { procedure only }\end{array}$} \\
\hline During sexual intercourse only & $2(0.6)$ \\
\hline \multicolumn{2}{|l|}{$\begin{array}{l}\text { Types of complications } \\
\text { known by mothers }\end{array}$} \\
\hline Bleeding & $32(99.9)$ \\
\hline Tetanus \& other infections & $6(1.8)$ \\
\hline $\begin{array}{l}\text { Painful intercourse \& } \\
\text { menstruation }\end{array}$ & $8(2.5)$ \\
\hline Delay in labor & $69(21.3)$ \\
\hline Urinary problems & $4(1.2)$ \\
\hline Bleeding \& Infection & $14(4.3)$ \\
\hline Bleeding \& Prolonged labor & $78(24.1)$ \\
\hline $\begin{array}{l}\text { Bleeding, Infection, \& Prolonged } \\
\text { labor }\end{array}$ & $103(31.8)$ \\
\hline Others & $10(3.1)$ \\
\hline
\end{tabular}

Among the mothers interviewed, to assess their level of knowledge $185(48.2 \%)$ were found having good knowledge regarding FGM and its complications, $163(42.4 \%)$ of mothers had fair knowledge, and $36(9.4 \%)$ were found having poor understanding with mean value at $95 \%$ confidence interval was $1.61(1.54,1.67)$ (Figure 1$)$.

\section{Attitude of mothers about circumcising their daughters and avoiding FGM in the future}

Majority of the mothers $372(96.9 \%)$ believe that FGM is a cultural 
practice and of which $254(68.2 \%)$ responded social stigma as a result of not circumcising their daughters and other consequences on the uncircumcised girl as believed by the mothers also include hyper sexuality, breaking house hold utensils and difficult of getting husband, $10(2.6 \%)$ don't know the reason for circumcising females, and $2(0.5 \%)$ mothers were respond that the practice is a religious act. Mothers attitude about circumcising their daughters indicate that 335 $(87.2 \%)$ do not want their daughters to be circumcised. and to avoid FGM in the future and 49(12.8\%) want to circumcise their daughters in the future. This shows a positive indicator for future behavioral change. Majority of the mothers 250(65.1\%) of the mothers do not discussed about FGM with their daughters because of different reasons, among which unusual to discuss such social practices with small children in the community and so that they were responded it as "taboo" (banned). ${ }^{13-16}$

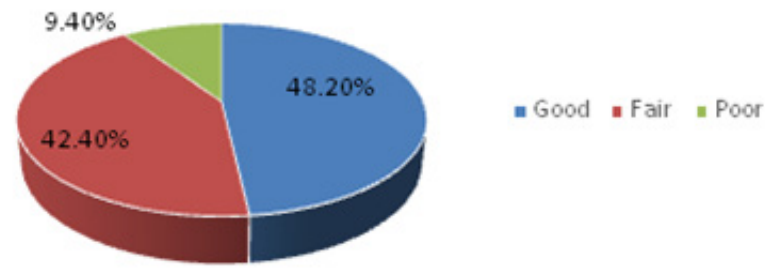

Figure I Pie chart showing respondents level of knowledge on FGM, Obi koji kebele, Wolisso woreda, South west shoa zone, Aug- Sep. 2009.

Practice of respondents regarding FGM and its complications. Among the mothers who have at least one daughter; 144 (37.5\%) had circumcised all of their daughters, $142(37 \%)$ circumcised none and, 53(13.8\%) circumcised some of their daughters. The remaining $45(11.7 \%)$ do not have a daughter. Out of the 771 daughters the mothers currently had 493(63.7\%) were found circumcised (Figure 2).

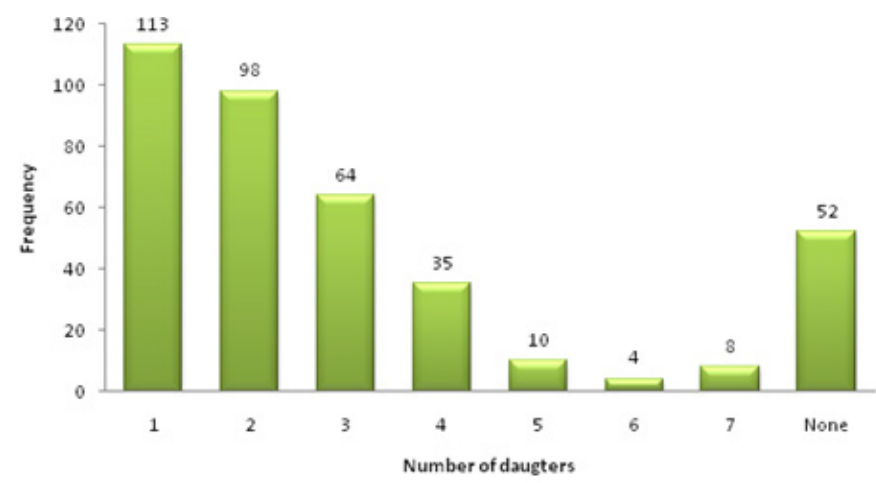

Figure 2 Bar chart showing number of daughters the respondents currently had, Obi koji kebele, Wolisso woreda, South west shoa zone, Aug- Sep. 2009.

In assessing the time when mothers practiced FGM in their last daughter $110(55.8 \%)$ did the last practice before 10years, $50(25.4 \%)$ practiced in the last five to ten years, $22(11.2 \%)$ two to less than five years and the other $15(7.6 \%)$ did it with in the previous two years. Majority of the circumcisions $(75.5 \%)$ were carried out in the age group between 1-6years, followed by $6-12$ years $(16.5 \%)$, birth to one year $14(7 \%)$ and the least age reported was from 12 years to time of marriage (Figure 3).

Majority of the circumcisions ( $95 \%$ ) were undertaken by traditional circumcisers and the remaining $5 \%$ were by traditional healers and traditional birth attendants. All of the circumcisions were performed by cutting the clitoris with razor blades. Thirty four (17.0\%) of the last circumcised daughters encountered different forms of health problems including bleeding 18(52.9\%), infection 10(29.4\%), and urinary retention $6(17.6 \%)$. However, almost all of the complications were non-fatal and managed at home with traditional medicines such as "Feto" and butter (Table 3) (Figure 4 \& 5).

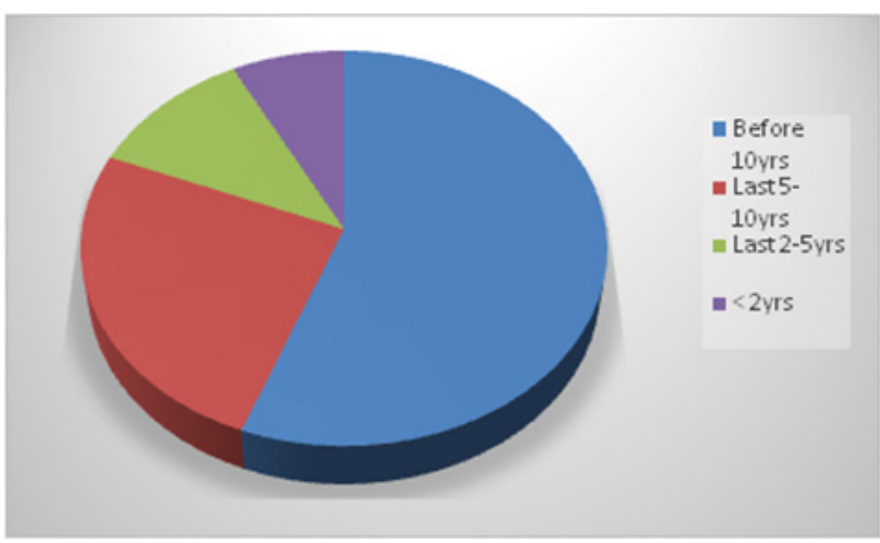

Figure 3 Pie chart showing the time when the mother circumcised her last daughter, Obi koji kebele, Wolisso woreda, South west shoa zone, Aug- Sep. 2009.

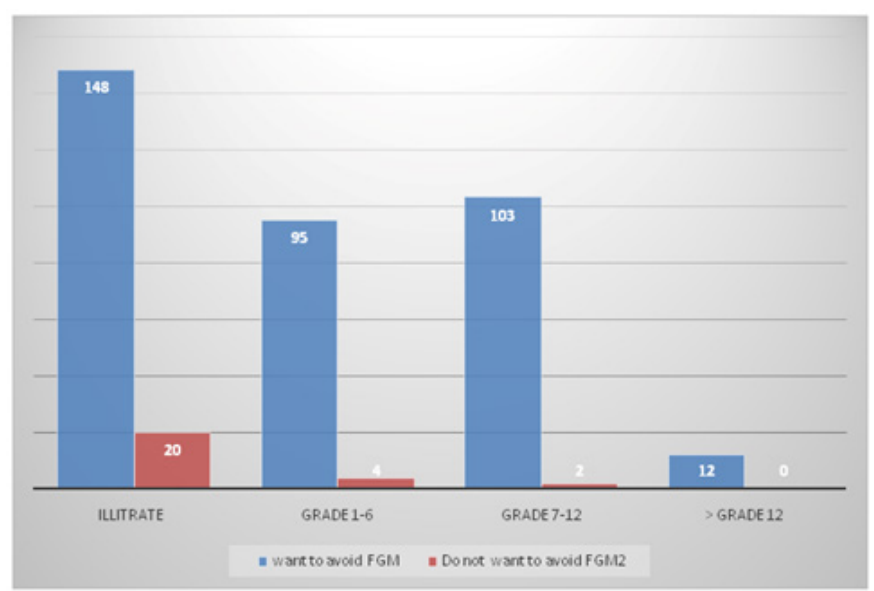

Figure 4 Bar chart showing attitude of mothers to circumcise her daughter with their educational status Obi koji kebele, Wolisso woreda, South west shoa zone, Aug- Sep. 2009.

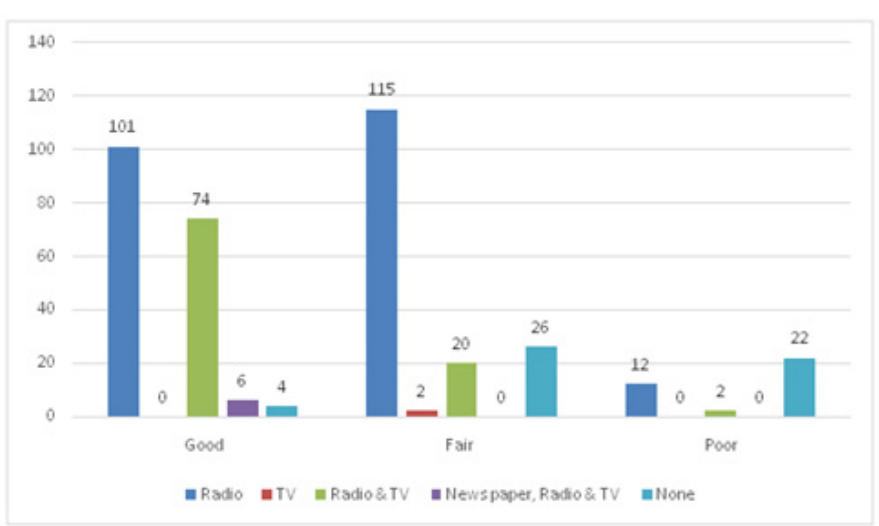

Figure 5 Bar graph showing mothers level of knowledge with possession of mass media Obi koji kebele,Wolisso woreda, South west shoa zone,Aug- Sep. 2009. 
Table 3 Socio demographic characteristics of respondents and the knowledge, attitude and practice on FGM and its complications, Obi koji kebele, Wolisso woreda, South west shoa zone, Aug- Sep. 2009

\begin{tabular}{|c|c|c|c|c|c|c|c|}
\hline \multirow[b]{2}{*}{$\begin{array}{l}\text { Background } \\
\text { Characteristics }\end{array}$} & \multicolumn{3}{|c|}{ Knowledge level } & \multicolumn{2}{|c|}{ Attitudinal status } & \multicolumn{2}{|l|}{ Practice level } \\
\hline & $\begin{array}{l}\text { Good } \\
\text { Number (\%) }\end{array}$ & $\begin{array}{l}\text { Fair } \\
\text { Number } \\
\text { (\%) }\end{array}$ & $\begin{array}{l}\text { Poor } \\
\text { Number } \\
\text { (\%) }\end{array}$ & $\begin{array}{l}\text { Favorable } \\
\text { Number } \\
\text { (\%) }\end{array}$ & $\begin{array}{l}\text { Unfavorable } \\
\text { Number (\%) }\end{array}$ & $\begin{array}{l}\text { Circumcise her } \\
\text { daughter Number } \\
(\%)\end{array}$ & $\begin{array}{l}\text { Not circumcised her } \\
\text { daughter Number } \\
(\%)\end{array}$ \\
\hline \multicolumn{8}{|c|}{ Educational Status } \\
\hline Illiterate & $136(6 \mid .5)$ & $32(14.5)$ & $53(24.0)$ & $87(75.7)$ & $28(24.3)$ & $130(83.3)$ & $26(16.7)$ \\
\hline Grade I-6 & $92(60.9)$ & $8(5.3)$ & $5 I(33.8)$ & $42(87.5)$ & $6(12.5)$ & $38(48.1)$ & $4 I(5 \mid .9)$ \\
\hline Grade 7-12 & $98(56.3)$ & $7(4.0)$ & $69(39.7)$ & $34(94.4)$ & $2(5.6)$ & $23(24.5)$ & $7 I(75.5)$ \\
\hline$>$ grade 12 & $10(41.7)$ & $2(8.3)$ & $0(0)$ & $12(100.0)$ & $0(0)$ & $4(50.0)$ & $4(50.0)$ \\
\hline \multicolumn{8}{|l|}{ Religion } \\
\hline Orthodox & $182(61.7)$ & $28(9.5)$ & $85(28.8)$ & $99(79.2)$ & $26(20.8)$ & $132(70.6)$ & $55(29.4)$ \\
\hline Muslim & $6(75.0)$ & $25.0(2)$ & $0(0)$ & $4(50.0)$ & $4(50.0)$ & $4(50.0)$ & $4(50.0)$ \\
\hline Protestant & $146(56.1)$ & $15(5.8)$ & $99(38.1)$ & $56(90.3)$ & $6(9.7)$ & $59(43.1)$ & $78(56.9)$ \\
\hline Catholic & $4(100.0)$ & $0(0)$ & $0(0)$ & $4(100.0)$ & $0(0)$ & $0(0)$ & $4(100.0)$ \\
\hline Others & $\mathrm{I}(100.0)$ & $0(0)$ & $0(0)$ & $\mathrm{I}(100.0)$ & $0(0)$ & $0(0)$ & $I(100.0)$ \\
\hline \multicolumn{8}{|l|}{ Ethnicity } \\
\hline Oromo & $297(57.7)$ & $45(8.7)$ & $173(33.6)$ & $139(82.2)$ & $30(17.8)$ & $180(61.0)$ & $115(39.0)$ \\
\hline Amhara & $25(69.4)$ & $0(0)$ & II(30.6) & $12(85.7)$ & $2(14.3)$ & $9(36.0)$ & $16(64.0)$ \\
\hline Gurage & $12(75.0)$ & $4(25.0)$ & $0(0)$ & $12(75.0)$ & $4(25.0)$ & $6(37.5)$ & $10(62.5)$ \\
\hline Tigre & $\mathrm{I}(100.0)$ & $0(0)$ & $0(0)$ & $\mathrm{I}(100.0)$ & $0(0)$ & $0(0)$ & $\mathrm{I}(100.0)$ \\
\hline \multicolumn{8}{|l|}{ Access to media } \\
\hline Have access & $315(60.7)$ & $23(4.4)$ & $|8|(34.9)$ & $137(90.7)$ & $14(9.3)$ & $157(53.6)$ & $136(46.4)$ \\
\hline
\end{tabular}

Table 4 Factors affecting knowledge, attitude and practice about FGM in Obi koji kebele, Wolisso woreda, South west Shoa zone, Aug- Sep. 2009

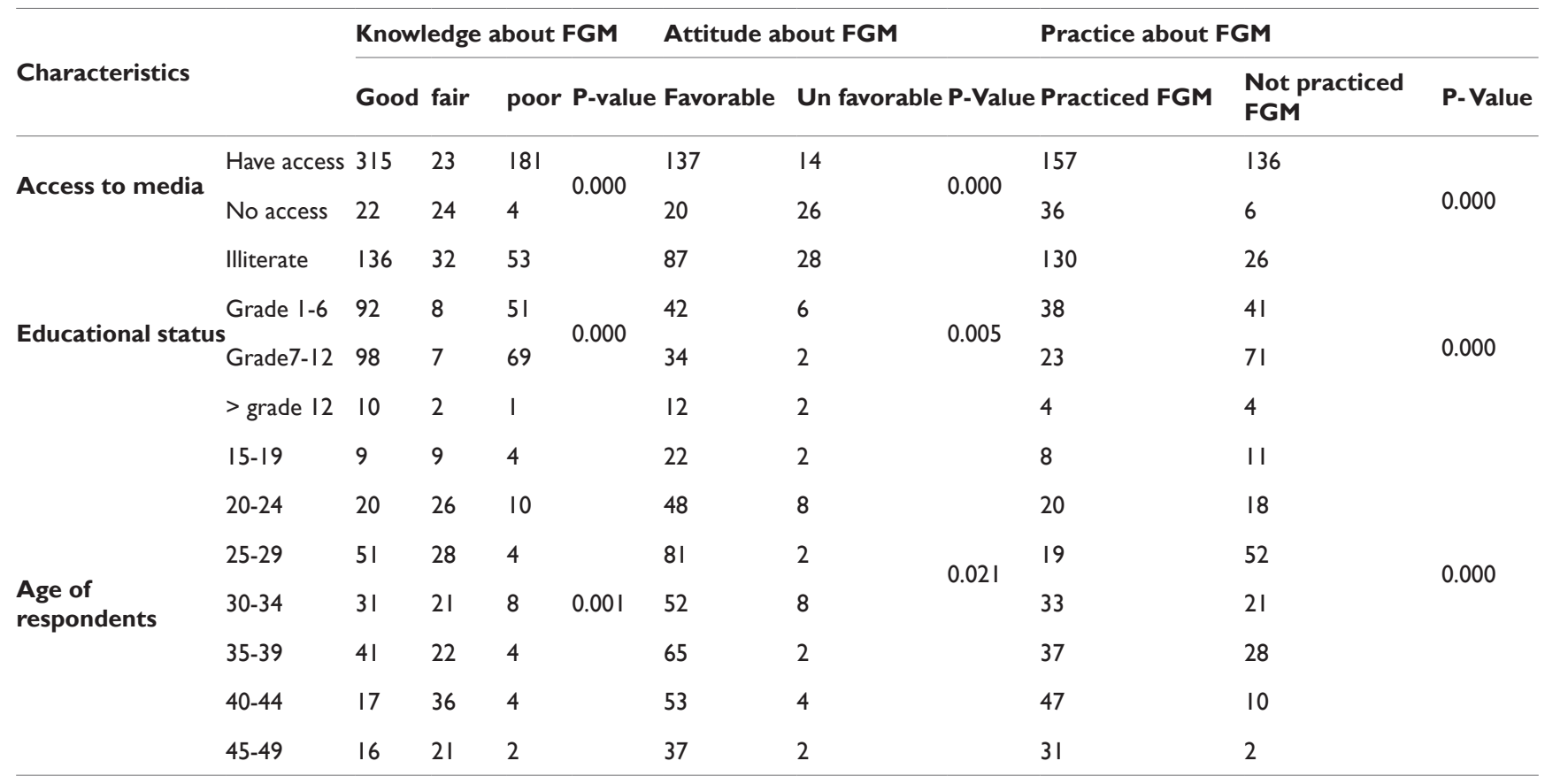




\section{Factors associated with Knowledge, attitude and practice}

Maternal education has very significant association with mothers' knowledge, attitude and practice about FGM with p-value of 0.001 , 0.005 and 0.001 respectively. Mothers who had access to different kinds of mass media were more likely found having good knowledge, attitude and practice than mothers who had no access to any kind of mass media with $p$-value of 0.001 for each. Maternal age was another variable which has very significant association with knowledge, attitude and practice of mothers with p-value of $0.001,0.021$ and 0.001 respectively (Table 4 ).

\section{Discussion}

The finding in this study showed that the magnitude of FGM was $63.7 \%$ which is lower than the national FGM prevalence that which is $72.5 \% .^{3}$ Respondents' level of knowledge was found to be good, fair and poor for $48.2 \%, 42.4 \%$ and $9.4 \%$ of the mothers respectively. In comparison with a survey conducted in Sudan regarding the public knowledge about the function of female's external genital organs showed that $33.7 \%$ had sufficient knowledge, $51.2 \%$ had limited information and $15.1 \%$ had no information. ${ }^{17}$ This study also showed that majority of the circumcisions $(95 \%)$ were undertaken by traditional circumcisers and the remaining $5 \%$ were by traditional healers and traditional birth attendants. ${ }^{18-21}$ This is even higher than the finding in the study conducted in North West Ethiopia where 72.4\%, of the procedures were said to be done by local health personnel. ${ }^{22}$ Regarding their knowledge on complications of FGM about $77.2 \%$ of the respondents said FGM could result in difficult labor, which was better than study conducted in North West Ethiopia that showed $63 \%$ of the respondents said FGM could result in difficulty labor, about $2.5 \%$ of the respondents said that FGM could result in painful menstruation \& sexual inter course which is less than the high school students respond $36.6 \%$, this great variation might be due to the respondents educational status, other $15.1 \%$ of respondents said FGM has no problem which is less compared to the high school students which reported $3 \% .^{23}$ While respondents attitude towards FGM $(87.2 \%)$ of the respondents want to avoid FGM which is better than the $75.7 \%$ of Sudanese mothers with positive response to the eradication of FGM. ${ }^{11}$ Regarding complications the mothers encountered in their life, $34(17.0 \%)$ including bleeding $18(52.9 \%)$, infection 10 (29.4\%), and urinary retention $6(17.6 \%)$, however, a study of 1836 circumcised Nigerian women found that the procedure (type I and II) did not attenuate sexual feelings or frequency of intercourse and was associated with a higher prevalence of abnormal vaginal discharge and pelvic pain. ${ }^{23}$ Majority of the circumcisions $(75.5 \%)$ were carried out in the age group between 1-6years, followed by 6-12years $(16.5 \%)$, birth to one year $14(7 \%)$ and the least age reported was from 12years to time of marriage, compared to a study showing in the rural Mossi areas of Burkina Faso, group female circumcisions are scheduled every three years in many villages. Girls aged from 5-8 are assembled by their mothers in to groups. ${ }^{24}$ Majority of the mothers $372(96.9 \%)$ believe that FGM is a cultural practice and of which 254 $(68.2 \%)$ responded social stigma as a result of not circumcising their daughters and other forwarded consequences on the uncircumcised girl as believed by the mothers also include hyper sexuality and breaking house hold utensils is in line to a given justification for the operation appears to be largely grounded in a desire to terminate or reduce feelings of sexual arousal in women so that they will be much less likely to engage in pre-marital intercourse or adultery. Parents in those cultures where FGM is common often feel that it is the only way that their girl children will remain "pure" until marriage. ${ }^{25}$

\section{Conclusion}

This study showed that: The magnitude of FGM was below the national prevalence of FGM by $8.8 \%$., all of the circumcisions were performed by cutting the clitoris (Type I circumcision).Maternal education was found as determinant of mothers' knowledge, attitude and practice about FGM. Literate (those who attended formal education) mothers were about two times more likely to have good knowledge about FGM and its complications than illiterate women (those who cannot read and write). Presence of mass media was another factor that strongly associated with mothers' knowledge and attitude. Mothers who had access to different kinds of mass media were more likely found having good knowledge than mothers who had no access to any kind of mass media. Majority of the respondents have a positive response to eradicate FGM in the future. Majority of the circumcisions were undertaken by traditional circumcisers and some were by traditional healers and traditional birth attendants. Most of the mothers that circumcised their daughters know FGM could result health problems. It is not only lack of knowledge that make parents subject their daughters to FGM, cultural expectations and pressures that is exerted on them rather than because of personal convictions regarding the rationality or acceptability of the practice.

\section{Recommendation}

Even though the magnitude of FGM in the study area is below the national prevalence it The advocacies through different mass Medias need to be continued in organized and in a way the community at rural area get information in accessible manner, Teachers, religious leaders and health professionals need to continue in teaching the society about consequences of FGM. Proper sensitization of youth, fathers, religious leaders and legislators in order to put great pressure on the mothers, grandmothers and on those who perform the practice. It is also very important to identify and teach those traditional circumcisers about complications of FGM, and also to make them participate in the movement to discharge this long held tradition from the community. The law enforcement bodies need to take strong action in those who perform FGM and teach the community about the legal prohibition of FGM. Mothers who do not circumcised their daughters need to be encouraged and taken as model to teach other mothers.

\section{Acknowledgments}

The researchers greatly acknowledge and appreciate Jimma University for the initiative to prepare this research on KAP of mothers on FGM by student researchers as part of Community based education in general and, providing the necessary technical and material support in particular. We also would like to forward our heartily feeling to Obi koji Kebele administrators and community for their cooperation by providing the pertinent information during the data collection period. At last not the least we would like to acknowledge the administration and stuff of St. Luke hospital for all their cooperation to our study.

\section{Conflict of interest}

Author declares that there is no conflict of interest.

\section{References}

1. Reproductive Health Service for Integrated Refresher Training. Health Extension and Education Center, Addis Ababa; 2006. 
2. Midwifery. Elsevier International Journal. 2008;24(2):214-225.

3. Harmful traditional practices under Ethiopian Laws, prepared by Ethiopian women lawyers association. 2005:3-10.

4. James H Sequira. "Female circumcision and Infibulation". Lancet. $1931 ; 2: 1054$.

5. Female Genital Mutilation. A joint WHO/UNICEF UNFPA statement. 1997.

6. WHO; 2006

7. Nawal Saadawi. The Hidden Faces of Eye: Women in the Arab World. London: Zed Press; 1980. 39 p.

8. Hedley R, Dorkenoo E. Child protection and female genital mutilation advice for health, education and social professionals. London; 1992.

9. Shandall AA. Circumcision and infibulations of females: a general consideration of the problem and a clinical study of the complications in Sudanese women. Sudan Med J. 1967;5(4):178-212.

10. Awa Thiam. La parole Aux Negressers. Paris: De Noel-Gonthier; 1978. $91 \mathrm{p}$.

11. Richard Anthoun. On the modesty of women in Arab Muslim villages in the accommodation of tradition". American Anthropologist. 1963;70(4):671-697.

12. Ahmed Shadall. Circumcision and infibulations of females: a general consideration of the problem and a clinical study of the complications in Sudanese women. Sudan Medical Journal. 1967;5:178-212.

13. Marie Bassili Assaad. Female Circumcision in Egypt: current Research and Social Implications. Cairo, American University in Cairo, Social Research Center. 1979. 14 p.

14. Oldfield Hayes. Female genital mutilation, fertility control, women's roles, and the patrilineage in modern Sudan: a functional analysis. American Ethnologists. 1975;2(4):634.
15. Ahmed Shandall. Circumcision and infibulations of females: a general consideration of the problem and a clinical study of the Complications in Sudanese women. Sudan Medical Journal. 1967;5:200.

16. Jomo Kenyatta, Facing Mount Kenya. The Tribal Life of the Gikuyu, Secker and Warburg. London; 1953.

17. Richard Anthoun. On the modesty of women in Arab Muslim villages in the accommodation of tradition. American Anthropologist. 1963;70:691

18. Okonofu FE, Larsen U, Oronsaye F. J Obstat Gynecol Neonatal Nurs. 1991;20:102.

19. FA Aziz. Gynecologic and obstetric complications of female circumcision. Int J Gynecol Obstet. 1980;17:560.

20. Lightfoot-Klein H, Shaw E. Special needs of ritually circumcised women patients. J Obstet Gynecol Neonatal Nurs. 1991;20(2):102-107.

21. Okonofu FE, Larsen U, Oronsaye F, et al. The association between female genital cutting and correlates of sexual and gynecological morbidity in Edo state, Nigeria. BJOG. 2002;109(10):1089-1096.

22. Amna AR, Hassan SNCTP. Female Genital Mutilation (FGM) psychosocio-sexual consequences and attitude change in Khartoum North and East Nile provinces. 2000.

23. Sudan Med Sheehan E. Victorian clitoriodoctomy. 1967;5:178.

24. Yohanis F, Kullehe A, Fasil M, et al. Gender Based Violence Among High School Students In North West Shoa Ethiopia. Ethiop Med J. 2005;43(4):215-221.

25. B Taverne. Ethics and communication strategy: female circumcision and AIDS in Burkina Faso. 1996. 